\title{
The Present Situation and the Development Research of Sports Teaching in China's Colleges and Universities
}

\author{
Jianjun Niu \\ College of sports medicine and rehabilitation, Taishan Medical University, China
}

Keywords: College Education, Physical Education, Teaching Present Situation, Development

\begin{abstract}
Based on the analysis of problems existing in the development of sports in colleges and universities teaching, the factors affecting the development of sports teaching in colleges and universities are: the sports teaching material system lags behind; PE teachers' quality should be improved; Lack of innovation concept sports teaching mode; Sports teaching facilities configuration needs to be perfect; Teaching evaluation system is not reasonable, and proposed the corresponding development strategy, this article aims to college sports teaching reform to develop healthy, more scientifically.
\end{abstract}

\section{Introduction}

With "sports law" and the width of the implementation of the "national fitness program outline", "lifetime sports" has become an important guiding ideology of the physical education teaching in colleges and universities in our country, this suggests that the growing demand for sports people. Physical education in colleges and universities shoulder the important task of cultivating physical education teachers. Sports teaching as an important part in college teaching, must be centered on students' comprehensive development, firmly establish a "health first" guiding ideology, strengthen the awareness of "lifetime sports", make the student lifelong physical exercise habit gradually, make the education goals in the direction of diversification, scientific, human nature development, cultivating meets the needs of social sports talents [1]. College students' physical quality in our country has a close relationship with the future of national physical quality, therefore, is of great significance in the research of the development of the sports teaching in colleges and universities.

\section{The present status of the sports teaching in colleges and universities of China}

The sports teaching material system is lagging behind. Education guiding ideology determines the teaching courses, which leads to its education condition and the result. As wave upon wave of global education reform tide wave of development, our actively explore and develop physical education to adapt to the development of colleges and universities sports teaching and curriculum system, has made remarkable achievements, but still lags behind the development of other subjects [1]. And, on the physical education curriculum design and teaching content, due to the bondage of competitive sports thought, still didn't get rid of the past a single, rigid, give priority to with competitive teaching model, not the quality of education and health education to physical education teaching, just the pursuit of the change of teaching contents and teaching forms of change. At the same time, because of the contemporary college students in physical form, function, hobbies, etc has made some changes, many teaching content cannot meet the needs of the development of their own, and they don't want to take part in physical exercise consciously.

All aspects of the quality of college $P E$ teachers remain to be improved. 1) In the development of physical education teaching in colleges and universities sports education thoughts are from the idea of "physical education" to "lifelong physical education and health" of modern sports thought transformation, that is, from strengthening physique to health first guiding ideology, this is the further deepening of our country school sports purposes the task. However, the current situation of college $\mathrm{PE}$ teachers' teaching guiding ideology: according to the survey at present most is still the guiding 
ideology of college physical education teaching in "promoting students physical health" and "master sports skills" as the primary guiding ideology of physical education teaching, respectively to more than $20 \%$ of the proportion of the total [2]. There are some dialectical relations in the physical education teaching, some teachers in teaching guiding ideology failed to grasp the "degree", improper choice, and orbit deviates from the reform of physical education, into the erroneous zone. Such as: do not see any point in establishing the guiding ideology of health first, think to strengthen students' physique itself the most can reflect the particularity of PE course goal; Think happiness education is "the sheep type" teaching and so on. Some of the old teaching ideas, make the sports teaching the one-sided emphasis on teaching sports skills and knowledge to the teacher as the center, it's virtually restrictions on the ability of the students' individual development and killing the students' creativity, ignoring the students scientific fitness provide theoretical guidance and method guidance, ignoring students' sports ability and the cultivation of the concept of lifelong sports.

2) Sports is originally a lively, interesting, lets the student the subject nature of free publicity, but because of some teachers' teaching methods and means lag behind, teaching form single teaching means with technology as the main line, emphasizing the standardization of the technical movements, is physical education into become monotonous and boring training, and the age of college students independent activity ability and creative relatively active period, old, and a single sports teaching to college students like to accept new things is a kind of oppression and bondage, eventually make the student to the movement of the boring thing. In addition, the current compulsory sports teaching still dominate the teaching of college sports course, is to the idea of "lifetime sports and health" sports and cultivating students' interest, the exercise habit of the teaching goal and specific teaching practice process [2]. Some teachers use the teaching methods of too much emphasis on their leading role in teaching lack of interactions with students. Teacher speak of any action is correct, the students just follow suit, neglected the student's main body function, cause the classroom teaching stylized, forced, teaching methods and inflexible, unfavorable to students' physical and mental development.

3) In many non-professional sports schools of planning, sports are often in scientific research, academic research, and even management after, is ignored and left out [2]. Thus seriously restrict the development of college PE teachers' innovation ability, make a lot of the status quo of college PE teachers, to teach subjects not in-depth research, lack of enthusiasm of innovation, knowledge, skills, old, degradation, is not up to the teaching of sports new knowledge, skills, and guidance. In teaching practice, hidebound, still make the teaching work in the increasingly rapid development of society.

Sports teaching mode of China's colleges and universities lacks innovative ideas. At present, the teaching of PE of universities and colleges in China, most of the teaching mode has been adopted for many years, the teaching model in a certain historical period to promote the development of China's university sports play a certain role. But, as the continuous deepening of the reform of sports teaching in colleges and universities in China, more and more of the old teaching mode has exposed the shortcomings of its development, already cannot adapt to the requirements of Chinese colleges and universities sports teaching [3]. Therefore, in order to adapt to China's future social requirement for talents, in order to adapt to the continuous development of society, to promote college students' harmonious and comprehensive development, cultivating "creative" talents, must reform the old teaching mode, to improve the teaching model of immature. At present, in China's colleges and universities sports teaching mainly adopt the teaching mode has the following kinds.

1) Kay's teaching mode. China's education system in comprehensive criticism and negation of humanistic thought at the same time, fully absorbed from the Soviet union's key's education thought. School sports as well as fully study the teaching mode of the Soviet Union, its basic pattern features are: perception - understanding - cement - use [3]. The teaching is divided into three elements: teachers, students and teaching materials. Education of unity, unified plan education teaching content system, unified plan. This kind of teaching mode while in a certain extent, to cultivate the students' sports skills, but its disadvantages are obvious.

2) Happy sports type teaching mode. Happy teaching mode first appeared in Japan, was introduced into China the middle $80 \mathrm{~s}$. Let students experience the happiness in this mode advocated in the teaching, student interest centered [3]. There is no denying the fact that these 
kinds of teaching modes is the active teaching atmosphere and mobilize students' participation in teaching, has the certain positive role. But in the physical education teachers have not system study and deep understanding of the teaching mode, it also has disadvantages.

3) "Three" is a kind of pay attention to raise student's sports foundation, sports ability, as well as the teaching pattern of physical exercise habits [2]. The detailed practice of colleges and universities sports curriculum is divided into three sections, open a basic course in grade one, grade two open special elective course, grade three and grade four open elective courses. The characteristics of the teaching mode is: pay attention to make a good student sports foundation, strengthen students' physique, and pay attention to cultivate the students' sports ability and form the habit of physical exercise.

4) The integration of teaching mode. This kind of teaching mode is the morning exercises, extracurricular activities, physical education organic union, to enhance students' physique, cultivate students' sports exercise habits [1]. In the implementation of the integrated teaching mode can fully use of space equipment. To strengthen the integrity of physical education teaching activities, but also has disadvantages.

5) The club type teaching mode. "Club model" is introduced to China in the late 20th century the ordinary university sports teaching, the teaching mode to students as the main body, teacher as the auxiliary, satisfies the requirement of students' interest, and intention, causes the student to set up a lifelong fitness sports view, promote the development of students comprehensive sports activity form, it is a part of quality education and happy sports, but to spread in China is not yet mature.

Sports teaching facilities configuration needs to be perfected. Sports field equipment and the lack of sports facilities is a big problem in sports teaching. There are still parts of the school physical education in calculation workload discounts, shortage of sports facilities equipped, etc. Directly affect the enthusiasm of teachers and the normal development of sports teaching and extracurricular activities. Except a few national key universities, colleges and universities sports equipment facilities is relatively backward, the space is tight [4]. Especially after the enrollment expansion of colleges and universities, the increase in the number of students' sports more crowded, some sports facilities in old aging, consumption badly worn, equipment, and site far cannot satisfy the needs of students' physical and mental development, which deeply influence sports teaching quality. In the process of sports teaching, for some of difficult movements, and the use of game tactics, teachers prefer to through the multimedia information technology to demonstrate and explain, in order to improve the teaching effect and quality. And the use of modern information technology, it is need to the corresponding equipment, needs the corresponding software and hardware to support. How to improve sports facilities as well as the application of modern information technology to improve the quality of physical education teaching is the development of the sports teaching in colleges and universities have to face the problem.

Physical education teaching evaluation system is not reasonable. At present, the sports teaching of middle school students' physical quality and physical education achievement assessment, although after reform of physical education workers constantly, perfect and has obtained some achievements, but there are some problems in general. Examination of the guiding ideology, and exam content and the form of highly consistent quality education concept, implement a standard, content, a request, cannot fully meet the demand of students' individual character, is also not an objective and fair to reflect the students' ability and level, restricted the students' all-round development and the individuality demand [4]. There are many unreasonable factors in the sports teaching in colleges and universities, in order to make China's sports teaching can better promote college students' comprehensive and healthy development, needs to explore unceasingly.

\section{The development of sports teaching in China's colleges and universities}

College physical education teaching material choice, should not only consider the needs of high-quality talent knowledge, have certain systematic and integrity, and to consider the needs of the students in the future career characteristics and life, to the maneuverability of the sports fitness in 
social life as a starting point, established to improve the students' health level, train the ability of lifelong physical exercise is the fundamental aim of college sports. College sports to cope with the existing curriculum and teaching material system to adjust, in order to enlarge the proportion of elective courses, extend the fixed number of year of the physical education curriculum, delete the old content, Settings and select scientifically meets the needs of students' physical fitness curriculum, teaching material content, form and the corresponding teaching system, arouses student's enthusiasm and initiative, fully excavate potential, outstanding lifetime fitness of students imparting knowledge, skill and ability, to adapt to the environment transformation conditions, students can still for fitness exercise.

Improve the comprehensive quality of physical education teachers. The quality of teachers directly affects the development of students and the knowledge to master degree of good or bad. To strengthen the construction of teaching staff, improve the comprehensive quality of physical education teachers, not only is the key to the implementation of quality education, and is the basic requirement of Chinese colleges and universities sports teaching reform. Physical education teachers in colleges and universities should strengthen their own professional theoretical knowledge, technical level and teaching ability and improving [5]. Teachers not only confined to the teaching ability, organization ability and the training ability, and must have strong self-study ability, creative ability and scientific research ability and aesthetic ability, in this way can we truly sports play a leading role in quality education, teachers to promote the development of China's colleges and universities sports teaching.

The value of sports teaching mode innovation. With the development of economy, the progress of the society, the older type teaching already cannot meet the requirement of the society a variety of sports. Physical education teaching should be adopted according to different teaching goal, the different teaching mode. In ordinary colleges and universities of China at present, there are three kinds of typical sports teaching modes: traditional sports teaching mode (also called basic course teaching mode), special options sports teaching mode and club sports teaching mode, no matter what kind of teaching mode is different, each have short. Because sports teaching are a multi-objective, function is very complex system. The action of any kind of teaching mode is not omnipotent is not eternal, so various teaching modes should be used in the sports teaching [6]. Can integrated the advantages and disadvantages of all kinds of teaching mode, combining the characteristics of ordinary university, according to the specific conditions of different students, organic combination of the three typical sports teaching mode.

To improve the material conditions of sports teaching. At present China's colleges and universities sports teaching venues, equipment and other hardware facilities is poorer, school of physical education teaching of money people is low, the leadership seriously enough., increase the investment of funds, is to improve the material conditions of sports teaching in colleges and universities sports teaching to adapt to the social progress and the future of higher education and rapid development of science and technology as well as the important factor of contemporary college students healthy demand, of which the government departments at all levels and the school unit should pay close attention [5].

Teaching evaluation system of scientific and democratic, pay attention to the comprehensive evaluation of "3 d". Comprehensive evaluation is refers to the so-called " $3 \mathrm{~d}$ " in the evaluation of physical education teaching effect, not only from the perspective of biological evaluation of the effect of its physiological function, but also from the perspective of psychological and social evaluation of physical education teaching effectiveness. "3d" the purpose of comprehensive evaluation from a mere rank method into the evaluation as an important means to promote the development of students, pay attention to playing the "form" of the evaluation, "diagnosis" and "improvement" role; Evaluation approach from a mere qualitative or quantitative method into the qualitative and quantitative combined, in the evaluation of importance to others at the same time, also attaches great importance to the self assessment, combining his evaluation and self-evaluation; The content of the evaluation from simple to student's evaluation to evaluate students' learning and evaluate teachers teach, from simple to evaluate students' knowledge study is given priority to into, intelligence and physique of 
students "all-round" such as art [6]. Through the reform of evaluation system, can make the students willing to accept evaluation, and actively participate in the evaluation, so as to achieve better teaching effect.

\section{Conclusion}

People in the 21st century will be to the sports teaching task and target have a new understanding, the guidance of lifetime sports thought will permeate throughout the period of teaching. Teaching reform to further cultivate the students in the form of emotion, improve the quality of the teachers, change the present teaching of sports teaching method "is given priority to with me", pay attention to cultivate students' innovative spirit and creative ability, to cultivate students' personality development, constructing the system of new physical education thought and adapt to the rapid development of science and technology in the new century, actively explore and promote the teaching and scientific research under the new situation, the combination of producers. Sports teaching reform should reform traditional sports teaching ideas, make it more in line with the students and the actual future education development needs, make the PE teaching reform in colleges and universities faces the society, for students, for the future.

\section{References}

[1] Zh. M. Mao, Sports teaching reform in the new field of vision, Beijing sports university press 2004. vol. 2, pp. 22-26.

[2] M. Wang, Physical education teaching reform should be based on social needs and discipline development, Hugh Tribune, education culture, 2009, vol. 3, pp. 18-21.

[3] H. T. Wang, Concerning some problems of the reform of physical education in colleges and universities, The Chinese sports science and technology, 2005, vol. 4, 32-35.

[4] L. Q. Yang, About the school sports stage cross type teaching mode, The Chinese sports science and technology, 2010, vol. 4, 60-63.

[5] Z. H. Qu. Sports teaching pattern question and answer, People's sport publishing house, 2008. vol. 2, pp. 8-11.

[6] J. J. Chen. New sports teaching, Tianjin people's publishing house, 2016, vol. 4, pp. 42-45. 